\title{
GABAergic transmission and modulation of anxiety: A review on molecular aspects
}

\section{Francisco Isaac Fernandes Gomes ${ }^{1}$, Maria Gerusa Brito Aragão², Mirna Marques Bezerra ${ }^{3}$ and Hellíada Vasconcelos Chaves ${ }^{4}$}

\author{
${ }^{1}$ Department of Pharmacology. Ribeirão Preto Medical School. University of São \\ Paulo. Avenida Bandeirantes, 3900. Monte Alegre. Ribeirão Preto-SP (CEP \\ 14049-900). E-mail: fifgomes@usp.br. \\ ${ }^{2}$ Department of Pediatric Dentistry. Ribeirão Preto Dentistry School. University of \\ São Paulo. Avenida do Café, S/No. Subsetor Oeste - 11 (N-11). Ribeirão Preto-SP \\ (CEP 14040-904). \\ ${ }^{3}$ Faculty of Medicine. Federal University of Ceará. Campus Sobral. Rua Conselheiro \\ José Júlio, S/№. Centro. Sobral-CE (CEP 62.010-820). \\ ${ }^{4}$ Faculty of Dentistry. Federal University of Ceará. Campus Sobral. Rua Conselheiro \\ José Júlio, S/№. Centro. Sobral-CE (CEP 62.010-820).
}

\begin{abstract}
Stress responses activate protective mechanisms to achieve homeostasis, but they can be detrimental when such responses become maladaptive. Anxiety relates to risk assessment of a potential threat and involves uncertainty regarding the anticipation of a threatening situation and it dampers quality of life. Gamma-Aminobutyric Acid (GABA) is the major inhibitory system in the central nervous system and plays a key role in the regulation of neuronal transmission in the brain, affecting many physiological and psychological processes. This mini-review aims to summarize key points concerned with the GABAergic transmission and basic aspects related to the GABAergic system in anxiety.
\end{abstract}

Keywords: Anxiety; GABA transmission; Pharmacotherapy; stress.
Received

January 15, 2019

Accepted

March 28, 2019

Released

April 30, 2019

Full Text Article

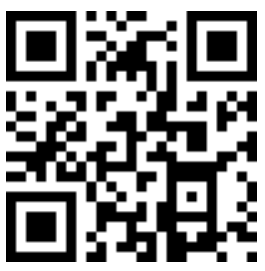

ORCID

(D) 0000-0002-8843-2945

Francisco Isaac

Fernandes Gomes

(ㄷ) 0000-0002-3334-1800

Maria Gerusa Brito Aragão

(ㄷ) 0000-0003-2146-4456

Mirna Marques

Bezerra 


\section{Introduction}

Stress is a state of threatened homeostasis during which a variety of adaptive processes are activated to produce "protective" physiological and behavioral changes to achieve homeostasis. The hypothalamicpituitary-adrenal (HPA) axis constitutes one of the major endocrine systems that maintain such responses to stressful conditions and it is likely to be one of the most prominent endocrine components of the stress response. Another crucial activated response to stressful conditions is the sympathetic nervous system which promotes catecholamine release from sympathetic nerve terminals (Juruena, 2014; Bali and Jaggi, 2015; Belda et al., 2015).

These mechanisms help to cope with stressful stimuli and account for the physiopathology of anxiety - a disabling disorder that imposes serious consequences on afflicted individuals. Anxiety relates to risk assessment of a potential threat and involves uncertainty regarding the anticipation of a threatening situation. It is triggered by less explicit and more generalized cues and is characterized by a more diffuse state of distress with symptoms of hyperarousal and pointless worries. Major depression is a common condition coexisting with other mental illnesses increasing the odds of substance abuse. Albeit the seriousness of anxiety, it has seldom been investigated and, consequently, its underlying neurobiological aspects remain poorly investigated (Fox and Kalin, 2014; Réus et al., 2014; Stein and Sareen, 2015).

Gamma-aminobutyric

acid

(GABA) is the major inhibitory system in the central nervous system and plays a key role in the regulation of neuronal transmission in the brain, affecting many physiological and psychological processes. Changes in its levels lead to an imbalance of excitatory/inhibitory signals causing neuropsychiatric disorders. GABA acts via ionotropic $\left(\mathrm{GABA}_{\mathrm{A}}\right)$ and metabotropic $\left(\mathrm{GABA}_{B}\right)$ receptors and either type of receptors are targets for many clinically important drugs used in the drug therapy of anxiety disorder. Drugs that act on $\mathrm{GABA}_{\mathrm{A}}$ receptors, for instance, benzodiazepines, barbiturates, neuroactive steroids, intravenous and inhalational anesthetics, and ethanol are of major importance (Möhler, 2012; Kumar et al., 2013).

Molecular interactions and the effects evoked by drugs acting at GABA receptors are complex due to the structural heterogeneity these receptors possess and the existence of a myriad of allosterically interconnected binding sites, let alone the numerous chemically distinct ligands (Beltrán et al., 2014; Chua and Chebib, 2017). As such, this review aims to summarize key points concerned with the GABAergic transmission and anxiety focusing on molecular aspects of GABA receptors per se and basic aspects related to the GABAergic system in anxiety.

\section{Molecular aspects of $\mathrm{GABA}_{\mathrm{A}}$ receptors}

The $\mathrm{GABA}_{\mathrm{A}}$ receptor is a $\mathrm{Cl}^{-}-$ channel involved in fast synaptic inhibition and member of a superfamily of transmitter-gated ion channels that includes the nicotinic acetylcholine, strychnine-sensitive glycine, and $5-\mathrm{HT}_{3}$ receptors. These ion channels are structurally similar, composed of five subunits that assemble to form an ion channel (Figure 1). Each subunit possesses four transmembrane domains and when the channel forms, these 
subunits organize in a way that their second transmembrane domains form the wall of the channel pore. In addition, there is a large intracellular loop between transmembrane domains three and four believed to be the target for protein kinases and to be necessary for subcellular targeting and membrane clustering of the receptor (Chebib and Johnston, 1999; Sieghart, 2006).

\section{$\mathrm{GABA}_{\mathrm{A}}$ receptor}

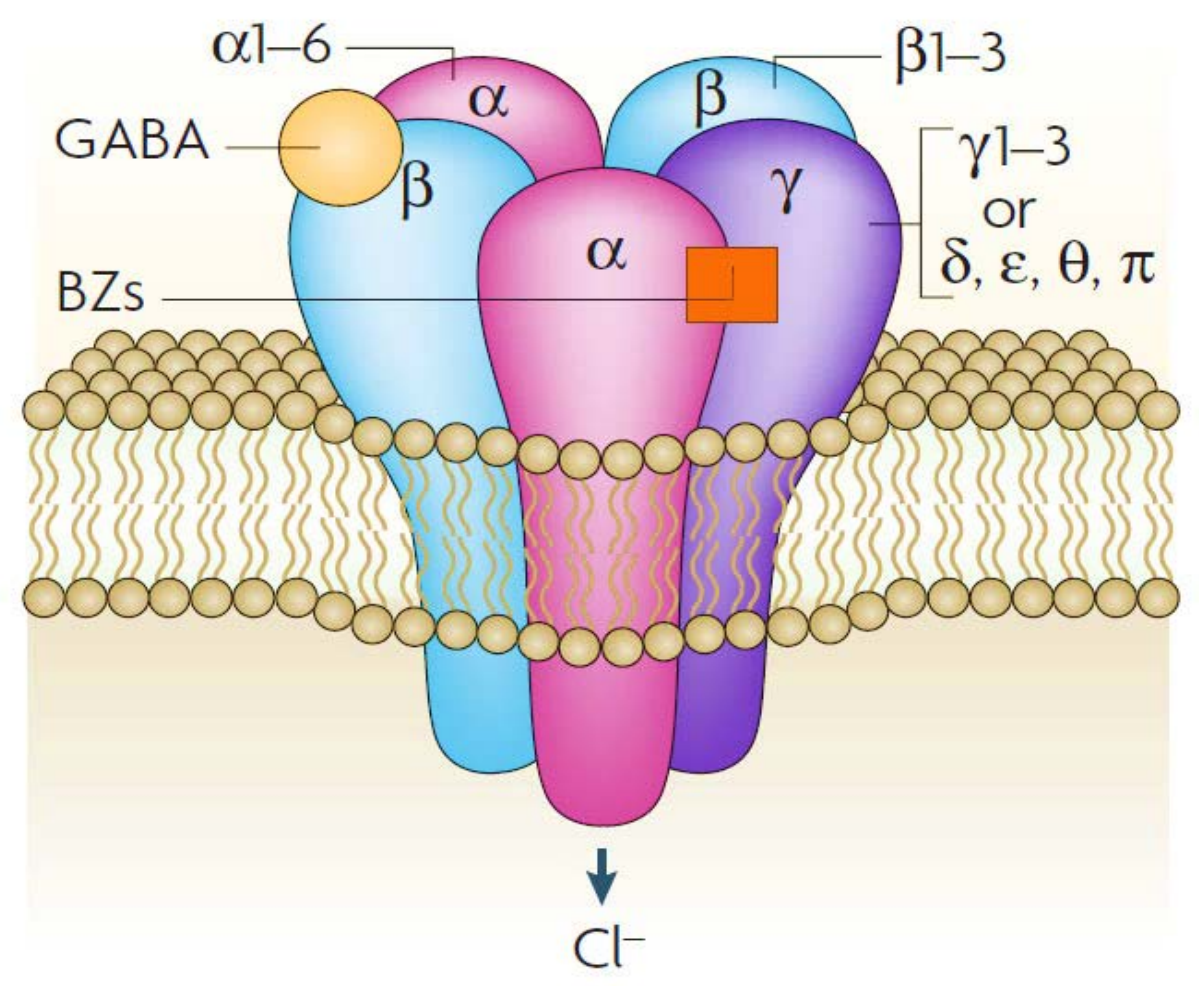

Figure 1. Schematic diagram of a $\mathrm{GABA}_{\mathrm{A}}$ receptor composition, structure, and binding sites for GABA and BZs (benzodiazepines). Source: Jacob et al. (2008).

$\mathrm{GABA}_{\mathrm{A}}$ receptors are selectively blocked by bicuculline and modulated by benzodiazepines, steroids, and barbiturates. Johnston, 1996 described $\mathrm{GABA}_{\mathrm{A}}$ receptors as the most complicated of the superfamily of ligand-gated ion channels in terms of many receptor subtypes and the variety of ligands that interact with specific sites on the receptors. So far, sixteen human $\mathrm{GABA}_{\mathrm{A}}$ receptor subunits have been characterized and grouped according to amino acid similarity and classified as: $\alpha$
$1-6, \beta 1-3, \gamma 1-3, \delta, \varepsilon, \theta$, and $\pi$ (Campbell et al., 2004; Karim et al., 2013)

The activation of $\mathrm{GABA}_{A}$ receptors by GABA is therefore not restricted to fast synaptic transmission alone and is in part dependent on subunit composition. These receptors are hetero-oligomeric, made up of a mixture of the mentioned subunits and, consequently, an immense array of combinations may exist for these receptor subtypes. However, if a fully functional $\mathrm{GABA}_{\mathrm{A}}$ receptor is to exist, an 
$\alpha, \beta$, and one other subunit type is necessary (Chebib and Johnston, 2000; Sinkkonen et al., 2000)

Regarding the six $\alpha$-subunits, $\alpha$ 1-3 are localized at synapses, $\alpha$ 4-6 subunits are extrasynaptically located and have higher sensitivity to GABA. The $\gamma$ 2-containing $\mathrm{GABA}_{\mathrm{A}}$ receptors can be found at both synaptic and extrasynaptic sites and combine with $\alpha 1-3,5-$ subunits to form benzodiazepine sensitive receptors. Each $\alpha$-subunit confers different physiological characteristics and displays differential regional expression profiles in the brain. The role of each $\alpha$-subunit in relation to benzodiazepine pharmacology has been elucidated using genetically modified mice in which a genetic mutation was introduced to individual $\alpha$-subunits to render the receptor subtype diazepaminsensitive. These studies found that the sedative, anterograde, amnestic, and partly the anticonvulsant actions of diazepam were mediated by $\alpha 1$ containing $\mathrm{GABA}_{\mathrm{A}}$ receptors, the anxiolytic-like effects were mediated by $\alpha 2$-containing $\mathrm{GABA}_{\mathrm{A}}$ receptors, and the myorelaxant action was mediated in part by $\alpha 3-$ and $\alpha 5-$ containing $\mathrm{GABA}_{\mathrm{A}}$ receptors. Moreover, the development of tolerance to the sedative action of benzodiazepines was linked to $\alpha$ 5containing $\mathrm{GABA}_{\mathrm{A}}$ receptors, while the addictive properties have been linked to $\alpha 1$-containing $\mathrm{GABA}_{\mathrm{A}}$ receptors (Rudolph et al., 2001; Chebib et al., 2004; Atack et al., 2005).

\section{Molecular aspects of GABA $_{B}$ receptors}

$\mathrm{GABA}_{\mathrm{B}}$ receptors predominantly couple to $\mathrm{G}_{\mathrm{i} / \mathrm{o}}$ proteins; the effect is primarily inhibitory via inhibition of presynaptic voltage-gated $\mathrm{Ca}^{+2}$ channels, activation of postsynaptic $\mathrm{K}^{+}$channels, and inhibition of adenylyl cyclase. These receptors are regulated either by receptor phosphorylation as well as their interaction with associated proteins. They have a central core domain of 7 transmembrane helices responsible for G-protein coupling (Figure 2). The GABA receptor is an obligatory heterodimer and is formed by 2 subunits, $\mathrm{GABA}_{\mathrm{B} 1}$ and $\mathrm{GABA}_{\mathrm{B} 2}$ (Emson et al., 2007; Li et al., 2013).

The former contains a large extracellular domain that binds GABA or other ligands such as baclofen; the latter couples the receptor with the effector $G$ protein. The activation of $\mathrm{GABA}_{B}$ receptors results from successive conformational changes of its two subunits. Two isoforms of $\mathrm{GABA}_{B 1}$ subunits exist $\mathrm{GABA}_{\mathrm{B} 1 \mathrm{a}}$ and $\mathrm{GABA}_{\mathrm{B} 1 \mathrm{~b}}$. They differ mostly due to the presence in GABA $_{B 1 a}$ of a pair of extracellular domains, which are termed sushi domains. They are conserved proteinbinding structures involved in protein interactions. The $\mathrm{GABA}_{\mathrm{B} 1}$ and $\mathrm{GABA}_{\mathrm{B} 2}$ receptor subunits interact with many extracellular and intracellular proteins that take part in trafficking, anchoring, and signaling (Benarroch, 2012).

$\mathrm{GABA}_{B}$ receptors are located presynaptically, postsynaptically, and on extrasynaptic membranes. Studies in transgenic mice show that isoforms containing $\mathrm{GABA}_{\mathrm{B} 1 \mathrm{a}}$ and $\mathrm{GABA}_{\mathrm{B} 1 \mathrm{~b}}$ possess differential synaptic distribution, location, roles, and pharmacologic features. Generally, GABA $\mathrm{B}_{1 \mathrm{a}}$ isoform is expressed in glutamatergic terminals, whilst $\mathrm{GABA}_{\mathrm{B} 1 \mathrm{a}}$ and $\mathrm{GABA}_{\mathrm{B} 1 \mathrm{~b}}$ isoforms are located at GABAergic terminals. Postsynaptic $G_{A B A}$ receptors can be formed from either $\mathrm{GABA}_{\mathrm{B} 1 \mathrm{a}}$ or $\mathrm{GABA}_{\mathrm{B} 1 \mathrm{~b}}$ subunits together with a $\mathrm{GABA}_{\mathrm{B} 2}$ subunit, which entirely depends on the cellular type. These spatial and temporal differences in the expression of the $\mathrm{GABA}_{\mathrm{B} 1 \mathrm{a}}$ and $\mathrm{GABA}_{\mathrm{B} 1 \mathrm{~b}}$ subunits suggest distinct functional roles these receptors play in a wide range of physiological conditions that could be fully therapeutically explored to allow for drug design and development studies to reach further towards a full comprehension of this system (Varani et al., 2014). 


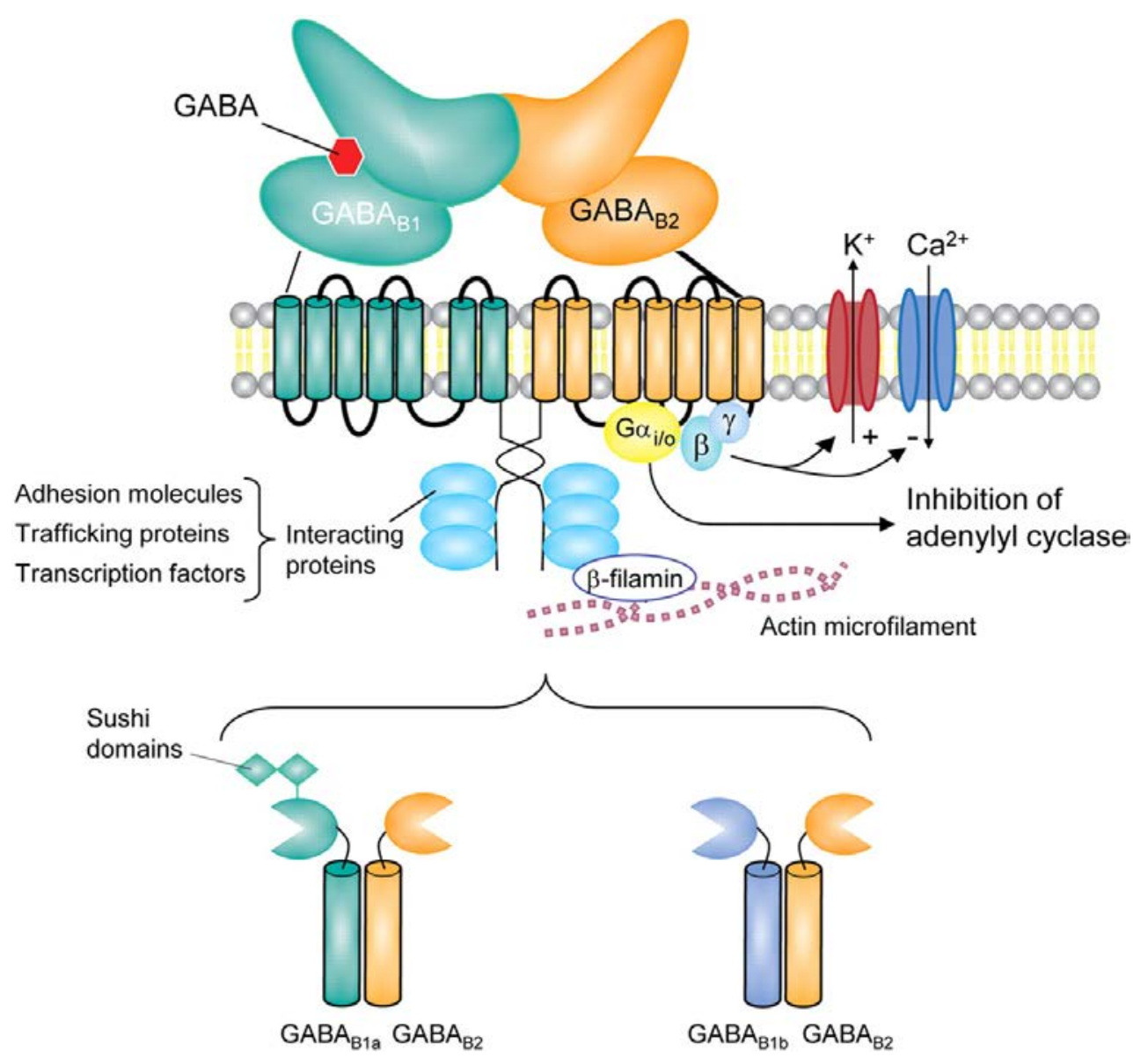

Figure 2. Schematic diagram of a $G_{A B A}$ receptor composition, structure, and binding sites for GABA and intracellular mechanisms. Source: Benarroch (2012).

\section{GABAergic transmission and anxiety}

Anxiety relates to risk assessment of a potential threat and involves uncertainty regarding the anticipation of a threatening situation. It is triggered by less explicit and more generalized cues and is characterized by a more diffuse state of distress with symptoms of hyperarousal and pointless worries. Anxiety disorders include five major debilitating subtypes disorders: generalized anxiety disorder (GAD), panic disorder (PD), obsessivecompulsive disorder (OCD), social anxiety disorder (SAD), and posttraumatic stress disorder (PTSD). Specific phobias are distinct but less debilitating. In anxiety patients, neutral stimuli or only slightly aversive stimuli can lead to extreme hyperarousal, emotional distress, and attempts to escape from or to avoid the anxietyinducing situation (Baldwin et al., 2005; 2010).

Drugs targeting GABAergic transmission have been widely employed for anxiety therapy. As discussed before, specific GABA subunits are involved in the anxiolytic effects of drugs and are held responsible for mediating such effects on pre-clinical studies. Additionally, specific GABA subunits lacking animals, either $\mathrm{GABA}_{\mathrm{A}}$ or $\mathrm{GABA}_{\mathrm{B}}$ subunits, are less prone to develop anxiety-like behaviors. This information hence provides us with a rationale for the 
development of selective drugs, opening avenues for further studies on the role of the diverse subtypes of GABA receptors in the physiopathology of anxiety (Chebib and Johnston, 2000).

A beneficial effect of GABAergic drugs in depression would be expected based on the available literature showing that patients can present a deficit in cortical GABA levels (Sanacora et al., 1999; Hasler et al., 2007), a deficit in cortical $\mathrm{GABA}_{\mathrm{A}}$ receptors (Klumpers et al., 2010) or a deficit in the number of cortical $\mathrm{GAB}_{\mathrm{A}}$ neurons (Rajkowska et al., 1999; 2007). Thus, these factors would be contributory in modulating anxiety states (Möhler, 2012).

The interest in the role of $\mathrm{GABA}_{\mathrm{B}}$ receptors in emotion regulation was fortified by the recognition that $\mathrm{GABA}_{\mathrm{B} 1}$ deficient mice show anxiety- and paniclike behavior. Conversely, chronic treatment of mice with the $\mathrm{GABA}_{B}$ receptor positive allosteric modulator CG39783, induced persistent anxiolysis without tolerance and ethanol interaction (Cryan and Kaupmann, 2005). In addition, $\mathrm{GABA}_{\mathrm{B}}$ receptors were implicated in mediating symptoms of depression and being possibly involved in the response to antidepressants (Ghose et al., 2010).

As discussed, the GABAergic transmission pharmacology is complex, and a plethora of components contribute to its functioning and network in the nervous system, let alone the many effects GABA per se possesses in other systems, acting as a major inhibitory signaling molecule. In anxiety states, the GABAergic system has shown a major contra-regulatory effect. A misbalance of this system is detrimental and, therefore, contributes to the physiopathology of anxiety disorders and other psychiatric conditions alike.

\section{Acknowledgments}

The authors acknowledge CAPES, CNPq and FUNCAP for financial supports. Gomes FIF acknowledges FAPESP for the research scholarship provided (grant number 2017/23815-0).

\section{Conflicts of interest}

The author declares no conflict of interest regarding this publication.

\section{References}

Atack, J. R. The benzodiazepine binding site of GABA(A) receptors as a target for the development of novel anxiolytics. Expert opinion on investigational drugs, v. 14, no. 5, p.601-618, 2005. https://doi.org/ 10.1517/13543784.14.5.601

Baldwin, D. S.; Allgulander, C.; Altamura, A. C.; Angst, J.; Bandelow, B.; den Boer, J.; Boyer, P.; Davies, S.; dell'Osso, B.; Eriksson, E.; Fineberg, N.; Fredrikson, M.; Herran, A.; Maron, E.; Metspalu, A.; Nutt, D.; van der Wee, N.; Vázquez-Barquero, J. L.; Zohar, J. Manifesto for a European anxiety disorders research network. European Neuropsychopharmacology, v. 20, no. 6, p. 426-432, 2010. https://doi.org/10.1016/j.euroneuro. 2010.02 .015

Baldwin, D. S.; Anderson, I. M.; Nutt, D. J.; Bandelow, B.; Bond, A.; Davidson, J. R. T.; Den Boer, J. A.; Fineberg, N. A.; Knapp, M.; Scott, J.; Wittchen, H. U. Evidence-based guidelines for the pharmacological treatment of anxiety disorders: Recommendations from the British Association for Psychopharmacology. Journal of Psychopharmacology, v. 19, no. 6, p.567-596, 2005. https://doi.org/ 10.1177/0269881105059253

Bali, A.; Jaggi, A.S. Clinical experimental stress studies: Methods and assessment. Reviews in the Neurosciences, v. 26, no. 5, p. 555-579, 2015. https://doi.org/10.1515/ revneuro-2015-0004

Belda, X.; Fuentes, S.; Daviu, N.; Nadal, R.; Armario, A. Stress-induced sensitization: The hypothalamic-pituitary-adrenal axis and beyond. Stress, v. 18, no. 3, p. 269-279, 2015. https://doi.org/10.3109/10253890.2015.10 67678

Belda, X.; Fuentes, S.; Daviu, N.; Nadal, R.; Armario, A. Stress-induced sensitization: The hypothalamic-pituitary-adrenal axis and beyond. Stress, v. 18, no. 3, p. 269-279, 2015. 
https://doi.org/10.3109/10253890.2015.10 67678

Beltrán González, A. N.; Pomata, P. E.; Goutman, J. D.; Gasulla, J.; Chebib, M.; Calvo, D. J. Benzodiazepine modulation of homomeric GABAAp1 receptors: Differential effects of diazepam and 4'-chlorodiazepam. European Journal of Pharmacology, v. 743, p. 24-30, 2014. https://doi.org/10.1016/ j.ejphar.2014.09.017

Benarroch, E. E. GABAB receptors: Structure, functions, and clinical implications. Neurology, v. 78, no. 8, p. 578-584, 2012. https://doi.org/10.1212/WNL.0b013e31824 7cd03

Campbell, E. L., Chebib, M.; Johnston, G. A. R. The dietary flavonoids apigenin and (-)epigallocatechin gallate enhance the positive modulation by diazepam of the activation by GABA of recombinant GABA A receptors. Biochemical Pharmacology, v. 68 , no. 8 , p.1631-1638, 2014. https://doi.org/ 10.1016/j.bcp.2004.07.022

Chebib, M.; Johnston, G. A. R. GABA-activated ligand-gated ion channels: Medicinal chemistry and molecular biology. Journal of Medicinal Chemistry, v. 43, no. 8, p. 14271447, 2000. https://doi.org/10.1021/ jm9904349

Chebib, M.; Johnston, G. The 'ABC' of GABA receptors: A brief review. Clinical and experimental pharmacology and physiology, v. 26, no. 11, p. 937-940, 2004. https://doi.org/10.1046/j.1440-1681. 1999.03151.x

Chebib, M.; Hanrahan, J. R.; Mewett, K. N.; Duke, R. K.; Johnston, G. A. R. Ionotropic GABA receptors as therapeutic targets for memory and sleep disorders. Annual Reports in Medicinal Chemistry, v. 39, no. 4, p.13-23, 2004. https://doi.org/ 10.1016/S0065-7743(04)39002-0

Chua, H. C.; Chebib, M. GABA receptors and the diversity in their structure and pharmacology. In: Geraghty, D. P.; Rash, L. D. (Eds.). Ion channels downunder. 1. ed. Cambridge, MA: Elsevier, 2017. (Advances in Pharmacology, v. 79). https://doi.org/ 10.1016/bs.apha.2017.03.003

Cryan, J. F.; Kaupmann, K. Don't worry "B" happy!: A role for GABA receptors in anxiety and depression. Trends in Pharmacological
Sciences, v. 26, no. 1, p. 36-43, 2005. https://doi.org/10.1016/j.tips.2004.11.004

Emson, P. C. GABAB receptors: structure and function. Progress in Brain Research, v. 160, p. 43-57, 2007. https://doi.org/ 10.1016/S0079-6123(06)60004-6

Fox, A. S.; Kalin, N. H. A Translational neuroscience approach to understanding the development of social anxiety disorder and its pathophysiology. The American Journal of Psychiatry, v. 171, no. 11, p. 1162-1173, 2014 . https://doi.org/10.1176/appi.ajp. 2014.14040449

Ghose, S.; Winter, M. K.; McCarson, K. E.; Tamminga, C. A.; Enna, S. J. The GABAB receptor as a target for antidepressant drug action. British Journal of Pharmacology, v. 162, no. 11, p. 1-17, 2011. https://doi.org/10.1111/j.1476-5381.2010. 01004.x

Hasler, G.; Van Der Veen, J. W.; Tumonis, T.; Meyers, N.; Shen, J.; Drevets, W. C. Reduced prefrontal glutamate/glutamine and $\gamma$ aminobutyric acid levels in major depression determined using proton magnetic resonance spectroscopy. Archives of General Psychiatry, v. 64, no. 2, p. 193-200, 2007. https://doi.org/10.1001/archpsyc.64.2.193

Jacob, T. C.; Moss, S. J.; Jurd, R. GABAA receptor trafficking and its role in the dynamic modulation of neuronal inhibition. Nature Reviews Neuroscience, v. 9, no. 5, p. 331-343, $2008 . \quad$ https://doi.org/ $10.1038 / \mathrm{nrn} 2370$

Johnston, G. A.R. GABAA receptor pharmacology. Pharmacology and Therapeutics, v. 69, no. 3, p. 173-198, 1996. https://doi.org/10.1016/0163-7258 (95)02043-8

Juruena, M. F. Early-life stress and HPA axis trigger recurrent adulthood depression. Epilepsy and Behavior, v. 38, p. 148-159, 2014. https://doi.org/10.1016/j.yebeh.2013. 10.020

Karim, N.; Wellendorph, P.; Absalom, N.; Johnston, G. A. R.; Hanrahan, J. R.; Chebib, M. Potency of GABA at human recombinant GABAA receptors expressed in Xenopus oocytes. Amino Acids, v. 44, no. 4, p. 11391149, 2013. https://doi.org/10.1007/ s00726-012-1456-y 
Klumpers, U. M. H.; Veltman, D. J.; Drent, M. L.; Boellaard, R.; Comans, E. F. I.; Meynen, G.; Lammertsma, A. A.; Hoogendijk, W. J. G. Reduced parahippocampal and lateral temporal GABAA-[ 11C]flumazenil binding in major depression: Preliminary results. European Journal of Nuclear Medicine and Molecular Imaging, v. 37, no. 3, p. 565-574, 2010. https://doi.org/10.1007/s00259-0091292-9

Kumar, K.; Sharma, S.; Kumar, P.; Deshmukh, R. Therapeutic potential of GABAB receptor ligands in drug addiction, anxiety, depression and other CNS disorders. Pharmacology Biochemistry and Behavior, v. 110, p. 174184, 2013. https://doi.org/10.1016/j.pbb. 2013.07.003

Li, X.; Risbrough, V. B.; Cates-Gatto, C.; Kaczanowska, K.; Finn, M. G.; Roberts, A. J.; Markou, A. Neuropharmacology comparison of the effects of the GABA B receptor positive modulator BHF177 and the GABA B receptor agonist baclofen on anxiety-like behavior, learning, and memory in mice. Neuropharmacology, v. 70, p.156-167, 2013. https://doi.org/10.1016/j.neuropharm .2013.01.018

Möhler, $\mathrm{H}$. The GABA system in anxiety and depression and its therapeutic potential. Neuropharmacology, v. 62 , no. 1 , p. 42-53, 2012. https://doi.org/10.1016/j.neuropharm .2011 .08 .040

Mombereau, C.; Kaupmann, K.; Gassmann, M.; Bettler, B.; Van Der Putten, H.; Cryan, J. F. Altered anxiety and depression-related behavior in mice lacking GABA $\mathrm{B}(2)$ receptor subunits. NeuroReport, v. 16, no. 3, p. 307310, 2005.

Rajkowska, G.; Miguel-Hidalgo, J. J.; Wei, J.; Dilley, G.; Pittman, S. D.; Meltzer, H. Y.; Overholser, J. C.; Roth, B. L.; Stockmeier, C. A. Morphometric evidence for neuronal and glial prefrontal cell pathology in major depression. Biological Psychiatry, v. 45, no. 9 , p. 1085-1098, 1999. https://doi.org/ 10.1016/S0006-3223(99)00041-4

Rajkowska, G.; O’Dwyer, G.; Teleki, Z.; Stockmeier, C. A.; Miguel-Hidalgo, J. J. GABAergic neurons immunoreactive for calcium binding proteins are reduced in the prefrontal cortex in major depression. Neuropsychopharmacology, v. 32, no. 2, p. 471-482, 2007. https://doi.org/10.1038/ sj.npp.1301234

Réus, G. Z.; Santos, M. A. B.; Abelaira, H. M.; Quevedo, J. Animal models of social anxiety disorder and their validity criteria. Life Sciences, v. 114, no. 1, p. 1-3, 2014. https://doi.org/10.1016/j.lfs.2014.08.002

Rudolph, U.; Mohler, H. GABA-based therapeutic approaches: GABAA receptor subtype functions. Current Opinion in Pharmacology, v. 6, no. 1, p. 18-23, 2006. https://doi.org/10.1016/j.coph.2005.10.003

Sanacora, G.; Mason, G. F.; Rothman, D. L.; Behar, K. L.; Hyder, F.; Petroff, O. A.; Berman, R. M., Charney, D. S.; Krystal, J. H. Reduced cortical gamma-aminobutyric acid levels in depressed patients determined by proton magnetic resonance spectroscopy. Archives of general psychiatry, v. 56 , no. 11 , p. 1043 1047, 1999. https://doi.org/10.1001/ archpsyc.56.11.1043

Sieghart, W. Structure, pharmacology, and function of GABAA receptor subtypes. Advances in Pharmacology, v. 54, no. 6, p. 231-263, 2006. https://doi.org/10.1016/ S1054-3589(06)54010-4

Sinkkonen, S. T.; Hanna, M. C.; Kirkness, E. F.; Korpi, E. R. GABA(A) receptor epsilon and theta subunits display unusual structural variation between species and are enriched in the rat locus ceruleus. The Journal of Neuroscience, v. 20 , no. 10 , p. $3588-3595$, 2000. https://doi.org/10.1523/jneurosci.2010-03588.2000

Stein, M. B.; Sareen, J. Generalized Anxiety Disorder. New England Journal of Medicine, v. 373, no. 21, p. 2059-2068, 2015. https://doi.org/10.1056/NEJMcp1502514

Varani, A. P.; Pedrón, V. T.; Machado, L. M.; Antonelli, M. C.; Bettler, B.; Balerio, G. N. Lack of GABA $B$ receptors modifies behavioral and biochemical alterations induced by precipitated nicotine withdrawal. Neuropharmacology, v. 90, p. 90-101, 2015. https://doi.org/10.1016/j.neuropharm.2014. 11.013 